\title{
Physical and Chemical Parameters and Some Heavy Metal for Three Rainy Season Months in Water and Sediments of Upper New Calabar River, Niger Delta, Nigeria
}

\author{
Awoteinm Dateme Isaiah George ${ }^{1}$, Jasper Freeborn Nestor Abowei² \\ ${ }^{1}$ Department of Fisheries and Aquatic Environment, Faculty of Agriculture, Rivers State University, \\ Port Harcourt, Nigeria \\ ${ }^{2}$ Department of Biological Sciences, Faculty of Science, Niger Delta University, Wilberforce Island, Nigeria \\ Email: pstawogeorge@yahoo.com,cebealse@yahoo.com
}

How to cite this paper: George, A.D.I. and Abowei, J.F.N. (2018) Physical and Chemical Parameters and Some Heavy Metal for Three Rainy Season Months in Water and Sediments of Upper New Calabar River, Niger Delta, Nigeria. Open Access Library Journal, 5: e4456.

https://doi.org/10.4236/oalib.1104456

Received: February 28, 2018

Accepted: May 5, 2018

Published: May 8, 2018

Copyright $\odot 2018$ by authors and Open Access Library Inc.

This work is licensed under the Creative Commons Attribution International License (CC BY 4.0).

http://creativecommons.org/licenses/by/4.0/

\begin{abstract}
The study of heavy metals in water and sediment was carried out in the upper reach of the New Calabar River, Niger Delta region in Nigeria. Three sampling stations were selected which were Choba, Ogbogoro and Aluu. Water and sediment samples were collected and analysed, using the buck scientific Atomic Absorption/Emission spectrometer 200 A model. Water Physico-chemical parameters were measured in situ. Dissolved Oxygen had an overall mean of $4.17 \pm 0.83 \mathrm{mg} / \mathrm{l}$, temperature had mean value of $28.34^{\circ} \mathrm{C} \pm$ $1.07^{\circ} \mathrm{C}, \mathrm{pH}$ had a mean value of $5.52 \pm 0.54$, electrical conductivity had a mean value of $1123.39 \pm 859.58 \mu \mathrm{s} / \mathrm{cm}$, BOD had mean value of $4.45 \pm 1.14$ $\mathrm{mg} / \mathrm{l}$, salinity had a mean value of $1.47 \pm 1.15 \mathrm{ppt}$ while TDS had mean value of $598.13 \pm 529.58 \mathrm{mg} / \mathrm{l}$. Result of heavy metals in water indicated that $\mathrm{Zn}$ had an overall mean value of $1.77 \pm 0.53 \mathrm{ppm}$, Cr had mean value of $0.65 \pm 0.21$ ppm, $\mathrm{Pb}$ had a mean value of $0.19 \pm 0.11$ while Fe had an overall mean value of $1.52 \pm 0.34 \mathrm{ppm}$. Heavy metals in sediment indicate higher concentration than in Water: $\mathrm{Zn}$ had an overall mean value of $7.90 \pm 2.59 \mathrm{ppm}, \mathrm{Cr}$ observed an overall mean value of $1.94 \pm 0.81 \mathrm{ppm}, \mathrm{Pb}$ had an overall mean value of $2.23 \pm 0.61 \mathrm{ppm}$, while Fe observed an overall mean value of $87.43 \pm 6.57$ $\mathrm{ppm}$. The result indicated that the source of heavy metals in the aquatic environment could be industrial effluent, domestic waste, dumping of scrap, vessel in the water way and runoff from agricultural land.
\end{abstract}

\section{Subject Areas}

Aquaculture, Fisheries \& Fish Science 


\section{Keywords}

Physico-Chemical Parameters, Heavy Metal, Rainy-Season, Water and Sediments, Upper New Calabar River

\section{Introduction}

Heavy metal can be described as a metallic element, which has a relatively high density as compared to water and is noted for toxicity [1]. Anthropogenic activities like mining activities, disposal of treated and untreated waste effluents containing heavy metals from different industries e.g. tannery, steel, plants, thermal power plants and uncontrolled use of heavy metal containing fertilizer and pesticide which enters the aquatic ecosystem through runoff, cause threat to the environment and bio-organism [2]. Heavy metals are found naturally in the earth and become concentrated in the aquatic environment as a result of human caused activities.

Lead is the most prevalent heavy metal contaminant [3]. In water, lead levels in the aquatic environments of industrialized societies have been estimated to be two to three times higher than those of pre-industrial level [4]. Heavy metals pollution of the aquatic environment has long been recognized as a serious environmental concern. In the sea, pollutants, are potentially accumulated in marine organisms and sediments, and subsequently transferred to man through the food chain [5]. For this reason, determination of the chemical quality of waters, sediments and aquatic organisms, particularly the contents of trace metals is extremely crucial for human health status [6]. Heavy metal pollutants are of great concern because they are produced in large amounts and discharged into the environments. They are toxic to aquatic organisms and bio-concentrate within the organisms sometimes to the levels greater than that in the environment [7]. Chindah and Nawaguibe [8], reported that heavy metals occur naturally in the aquatic ecosystem and also as a result of waste discharges from industries and agricultural runoff, increased urbanization and as a result of increase in human population. Furthermore, he reported that heavy metals are biologically under-gradable when appeared in higher concentration but easily bio-accumulated in the tissue of aquatic organisms.

The sediment is a mixture of several components of mineral, species as well as organic debris, represented as ultimate sink for heavy metal discharge into the aquatic environment [9]. Yi et al., [10] observed that when heavy metals are discharge into the aquatic environment they can be absorbed by suspended solid and they strongly accumulate in the sediment. Moreover the sediment acts as a sink and also as a source of heavy metal [11]. According to Odiete [12] metals and other fluvial contaminant in suspension or solution do simply flow down the stream was they form complexes with other compounds, settling in the bottom and absorbed in the sediment. 
Sediments are commonly used as indicators for the degree of pollution in the aquatic environment [13]. According to Davies et al:; [14], heavy metal concentrates more in sediment than in water. According to Issa et al., [15], sediment is an integral part of the aquatic environment providing habitat feeding, spanning and accumulation of heavy metal in the water columns. Contaminated sediment can cause lethal and sub-lethal effect in benthic and their sediment associated organism [16]. Sediments are integral part of the aquatic environments providing habitat, feeding and rearing areas for shell fish, fish and other fauna [12]. It serves both as a reservoir as well as source of contaminants to the water column. Usually, the quantity of contaminants found accumulates in sediment to elevated levels.

Water is the most often polluted phase in the environment, which is attributed to the ultimate ending of contaminant in air, soil and land into the aquatic environment through local precipitation, water surface runoff and leaching of rock and solid waste [17]. According to Degregori et al., [18], Man's activities such as mining, industrial processing of ores and metals, still remain the principal cause of the increasing amount of heavy metal in water; which are been dump in the Aquatic environment. One of the most challenging pollution issues is the accumulation of heavy metal in water owing to toxicity, abundance, persistence and subsequent bioaccumulation of heavy metal [19]. Omitoyin and Ajani [20] investigate the accumulation levels of the metals (copper, lead and zinc) in water samples in addition with studying the feeding habits of fish species in water, while Ayeloja et al., [21] studied Copper, Lead Cadmium, Zinc, Chromium and Manganese concentration in water. The discharge of heavy metal environment as pointed out by Abowei and Sikoki [22] that heavy metal could damage the ecosystem quality rendering water unsuitable to the intending use.

Heavy metal was of critical concern due to their ability to bio-accumulate in aquatic environment and their toxicity [23] as well as persistency in the natural environment. Recently different types of biomarkers have been studied and evaluated for their acceptability to detect the biological effects as a biomonitoring tool [24]. According to Dirican et al. [25], heavy metals are the most important forms of aquatic pollutants and may accumulate in the tissues of fish, which are often at the top of the Aquatic food chain. The progressive and irreversible accumulation of metal in various organs of aquatic organism always leads to mental related diseases in the long run because of the toxicity of the metals. Among the aquatic organism, fishes are the important member which often accumulates metals in different parts of their body. The consequences of heavy metal pollutants in aquatic environment lie in two aspects with respect to their impact.

Firstly, heavy metal has the potency to persist in natural aquatic ecosystems of an extended period. Secondly they have the ability to accumulate in successive levels of the biological chain. Thereby causing lethal and sub-lethal diseases [26]. There toxicity has been demonstrated long ago [27]. Exposure to heavy metals have been linked to developmental retardation [28]. Heavy metal toxicity in- 
clude the binding of heavy metal more strongly to functional site that are normally occupied by essential functional groups of biologically important molecules, making them inactive, decomposing essential metabolites and changing the osmotic balance around the cell [29]. The degeneration and malformation of the cell reflect one aspect of the cytotoxic input after exposure to pollution and serve as an index of cytotoxicity [30]. Biomonitoring is a promising tool for identifying pollutants (bio-indicators) that affect human and environmental health, is especially useful with organisms, which are exposed to biological system [31]. According to FAO/WHO [32] water is one of the most valuable natural resources and it is essential for the maintenance of all forms of life. Water temperature is one of the most important characteristics of an aquatic ecosystem.

O'connor [33] observed that temperature controls the rate of fundamental biochemical process in organism and consequently changes in the environmental temperature which influences population species. Temperature is measured in Celsius $\left({ }^{\circ} \mathrm{C}\right)$. Goldman and Horne [34] describe biochemical oxygen demand as the amount of oxygen required for microbial metabolism of organic compounds in water. Fish and other aquatic organism may die when oxygen is depleted by microbial metabolism [35]. Lau et al:; [36] describe conductivity as the measure of the ability to conduct electric current and is the reciprocal of resistance. It was also observed by Lau et al.; [36] that the conductivity ion comes from dissolved salts and inorganic materials such as alkalis, chlorides, sulfides and carbonate compound. Conductivity is measured in micro semem per centimeter $(\mu \mathrm{s} / \mathrm{cm})$.

According to WHO [37]. Dissolved oxygen can affect the solubility and availability of nutrients, which can be released from sediments under conditions of low dissolved oxygen. Turbidity in open water may be cause by growth of phytoplankton and other human activities which can lead to high sediment level entering the aquatic ecosystem. Turbidity is described as the amount of clouding in water. Turbidity in the aquatic environment is mainly caused by Silt, sand and mud; Bacteria and other germs; Chemical and precipitates. Turbidity is measured in Nephelometric turbidity unit NTU [16].

Salinity is a measure of the concentration of the total dissolved salt present in water. Salinity is measured in part per thousand [38]. Power of Hydrogen $(\mathrm{pH})$ refers to the measure of hydrogen ions $\left(\mathrm{H}^{+-}\right)$in water which determine its acidic, alkaline or neutral character. Any particular water is a mixture of acids and bases and is the result of acid-base titration processes [39]. Seasonal variation in $\mathrm{pH}$ with higher values in the wet than dry season has been recorded [39]. Situation of non-seasonality in $\mathrm{pH}$ also has been recorded in some tropical rivers by Chindah and Braide [40] in the New Calabar River; Nkanta [41] in the Bonny River. Boyd and Lichtkoppler [42] reported that $\mathrm{pH}$ of water body rises during the day and decreases at night due to the removal of carbon (iv) oxide by aquatic plant between 6.5 and 8 ; while in natural water $\mathrm{pH}$ value ranges from between 4 to 9 . 
The New Calabar River located in Rivers State, the Niger Delta ecological zone of Nigeria is an economically important water way [43]. It spans from Isiokpo at the Upper reach in the North to the Bight of Bonny in the South. This river is unique owing to its brackish water nature from Iwofe area to Choba/Aluu juncture at the lower reach and freshwater from Aluu to Isiokpo at the upper reach. This river is of great economic importance as it supports a number of communities in the area with a wide varieties of human and industrial developmental activities. It has been reported by the locals, around its course to have a unique biodiversity with a variety of indigenous ornamental and food fishes; however there is a paucity of information on this river system [35].

The pollution of aquatic environment with heavy metals has been a turning issue all over the world. This is because of their destructible and most of them have toxic effect on organisms [44]. Over the last few years, there has been a growing interest in determining the level of heavy metal in the brackish water environment. This has led to attention being drawn to the measurement of contamination level in the water [45]. Heavy metals including both essential and non-essential elements have a particular significance in eco-toxicology, since they are highly persistent and all have the potential of being toxic to living organisms. Heavy metal concentrations in aquatic ecosystems are usually monitored by accessing their concentrations in sediments, biota and water [46]. They generally exist in low quantities in water but subsequently attain considerable levels of concentration in sediments and biota [46]. Many of these heavy metals are toxic to organisms at low concentration [47]. The aquatic environment is encompassing and important as aquatic organisms may acquire heavy metals into their bodies directly from the water via their gills or food chain mechanisms [48].

The effects of heavy metals concentration in the aquatic environment have attracted global attention [49]. The heavy metals concentration in water sediments and biota is caused by both natural and anthropogenic activities [50]. The heavy metal pollution is increasing due to the effect of urbanization and industrialization. Pollution caused by heavy metals is currently the major problem in many developing countries including Nigeria. Water and sediments are commonly used as indicators for the state of pollution in any aquatic environment [51].

The Upper New Calabar River is connected to many river systems and also serve as point of discharge of domestic, industrial wastes in some areas along the length of the river and also runoff from agricultural lands always flow into the river system at different points. Metals are those elements whose atoms ionize by electrons loss. Metals are generally known to be reducing agents because they tend to donate their electrons readily during chemical reactions [52]. Heavy metals are inorganic elements essential for growth in trace or very minute quantities, toxic and poisonous in relatively higher concentrations, biologically undegradable but easily assimilable and bioaccumulated in the protoplasm of aquatic organisms [53]. In natural aquatic ecosystems, metals occur in low concentra- 
tions usually nanograms to micrograms per litre. The occurrence of these heavy metal contaminants especially in excess of natural levels in recent times has become a problem of increasing concern. Some examples of these metals include: lead $(\mathrm{Pb}) \mathrm{Zinc}(\mathrm{Zn})$, Cadmium (Cd), Mercury ( $\mathrm{Hg}$ ), Copper ( $\mathrm{Cu})$, Iron (Fe), etc. Although heavy metals are loosely defined as metals with relatively high densities, atomic weights or numbers; It is widely spread recognized and are usually contaminants of terrestrial and aquatic ecosystem. Many of these heavy metals are toxic in low concentration to aquatic lives [47]. Some of these heavy metals, such as $\mathrm{Cd}$ and $\mathrm{Pb}$ are toxic to living organisms at quite low concentration, whereas others such as $\mathrm{Zn}$ and $\mathrm{Cu}$ are biologically essential and are natural constituents of aquatic ecosystem but only become toxic at very high concentration [54].

\section{Materials and Methods}

\subsection{Study Area}

The study area is situated in two local government Area; Ikwerre and Obio/Akpor) In Rivers State, one of the oil producing state in the Niger Delta, Nigeria. The study was carried out in the Upper New Calabar River (UNCR). The study area location is within the coordinate: longitude $7^{\circ} 03^{\prime \prime} \mathrm{E}$ to $7^{\circ} 02^{\prime \prime} \mathrm{E}$ and latitude $4^{\circ} 42^{\prime \prime} \mathrm{N}$ to $4^{\circ} 25^{\prime \prime} \mathrm{N}$. The fact is that enough work has not been done in the Upper New Calabar River on heavy metals. Many authors who worked in this river concentrated on other aspects, without giving attention to the heavy metal present in the Upper New Calabar River. A lot of companies are sited along the bank of the river, where effluents are discharged into the water and bio-accumulated. Companies such as Cement company, Oil company, dredging company etc, operating along the shores of the river. The sampling stations in the Upper New Calabar River (UNCR) and its tributaries are located in Rivers State, Niger Delta, Nigeria. Three sampling stations were chosen along the course of the water body based on the ecological settings and human activities in the area. The stations include; Ogbogoro (Station 1), Choba (Station 2) and Aluu (Station 3).

\subsection{Sample Collection}

Samples collection was carried out monthly for a total duration of three months; between April and June 2017. Water physiochemical parameters were also measured in addition to determining the concentration of heavy metals in water and sediment samples which were obtained from each of the sampling stations. Sediment samples were collected from each of the sampling station using the Eckman Grab in Which the top $20 \mathrm{~cm}$ of the bottom sediment was obtained and kept in labeled sterile bags [55]. The bags were rinsed with water at the point of sediment collection before the sediment sample were put into them.

Physico-chemical parameter such as dissolved oxygen, Temperature, Total dissolve solid, salinity, $\mathrm{pH}$, Biological oxygen Demand (BOD) and Electrical 
Conductivity were measured in-situ using (HORIBA) Model 4 - $10 \mu$ meter at the various stations. Water parameters measurement were done by immersing the meter probe into the water body and taking the reading after being stable. The meter was calibrated with buffer solution before it was used. Water samples for the heavy metal analysis were obtained from the respective stations at the depth of $50 \mathrm{~cm}$ below the surface and stored in $100 \mathrm{ml}$ glass bottle in a refrigerator at $4^{\circ} \mathrm{C}$ [56]. Sediment sample weighing $5.00 \mathrm{gm}$ of the well dry and grounded. After it has been sieved into the beaker. Add $9 \mathrm{ml}$ of $\mathrm{HNO}_{3}$ as oxidizing acid to break the sample matrix and $3 \mathrm{ml}$ of Hydrochloric acid. Add small amount of Anti-bumping to it, while heating on mantle. Rinse with some volume of distilled water. Heat until it volume reduced to about one third of its original volume and its color clear and turns yellowish. Stir it while on hot plate. Filter it with whatman filter paper make its final volume to $50 \mathrm{ml}$ with distilled water, them Aspirate with Atomic absorption Spectrophotometer (AAS). Aspiration procedure for Direct Air Acetylene flame method of sample with AAS: Atomic absorption spectrophotometer, Model S, series 710,690.

Install a hollow cathode lamp of the desired metals in the instrument, set the wavelength dial according to the metals of interest being used. Then turn on the instrument apply to the Hollow cathode lamp the current suggested by the manufacturer. Allow the instrument to warm up energy so as to stabilize for $10-20$ minuts. Turn on air and adjust its flow rater to that specific demand metals to give maximum sensitivity for the metal being measured. Ignite the flame and allow it to stabilize for few minutes. Aspirate the blank consisting of De-ionized water. Zero the instrument and aspirate the standard solution and adjust it aspiration rate of the Nebulizer to obtain maximum sensitivity. Aspirate the blank again and re-zero the instrument. Then analyse all the samples and read the concentration in ppm or $\mathrm{Mg} / \mathrm{l}$ directly from the instrument Readout. Extinguish the flame turning off first the Acetylene and the air. If the sample is dilute multiply with the dilution factor and calculate in microgram/litre or in ppm. Water samples were acidified with concentrated trioxonitrate (v) acid $\mathrm{HNO}_{3}$. They were carefully filter using Millipore filtration unit devise and filtered through $0.45 \mu \mathrm{sm}$ membrane filter paper and the water sample were analysed for heavy metals using the Atomic Absorption Spectrophotometer (Buck Scientific 210/211 VGP Model).

\section{Data Analysis}

The data obtained were subjected to descriptive and inferential statistics. Descriptive statistics that were used; standard deviation and average mean to describe each of the water parameters as well as the concentration of heavy metal in water and sediment. That is the values obtained from the physiochemical and heavy mental analysis were subjected to statistical software such as SPSS to determine the means, standard deviation, correlation and to separate the mean at $\mathrm{P}<$ 0.05. Analysis of Variance (ANOVA) was used to test for significant differences 
in heavy metal content in water and sediment. One way ANOVA was used in all cases of mean metal level comparison at $5 \%$ level of significance.

\section{Results}

The results of the water physiochemical parameters obtained monthly across the station; during the research study indicated that DO had value between 4.00 and $4.37 \mathrm{mg} / \mathrm{l}$ in which the highest value $(4.37 \pm 0.35 \mathrm{mg} / \mathrm{l})$ was observed in May and the lowest value $(4.00 \pm 1.44 \mathrm{mg} / \mathrm{l})$ was recorded in April. Temperature ranged between $27.83^{\circ} \mathrm{C}$ and $29.27^{\circ} \mathrm{C}$, April had the highest mean value $\left(29.27^{\circ} \mathrm{C} \pm\right.$ $\left.1.57^{\circ} \mathrm{C}\right)$ while the lowest value $\left(27.82^{\circ} \mathrm{C} \pm 0.38^{\circ} \mathrm{C}\right)$ was observed in May. $\mathrm{pH}$ gave a mean range between 5.22 and 5.81, May recorded the highest value $(5.81 \pm$ $0.22)$ while the lowest value $(5.22 \pm 0.21)$ was observed in April. Electrical conductivity ranged between 405.67 and $1766.67 \mu \mathrm{s} / \mathrm{cm}$, April had the highest value $(1762.67 \pm 1028.60 \mu \mathrm{s} / \mathrm{cm})$ while the lowest value $(405.67 \pm 68.53 \mu \mathrm{s} / \mathrm{cm})$ was observed in June. Biological Oxygen Demand ranged between 4.03 and 5.11 $\mathrm{mg} / \mathrm{l}$, were the highest value $(5.11 \pm 1.19 \mathrm{mg} / \mathrm{l})$ was observed in May and the lowest value $(4.03 \pm 1.14 \mathrm{mg} / \mathrm{l})$ was observed in June. Salinity ranged between 0.08 and $2.44 \mathrm{ppt}$, were the highest value $(2.44 \pm 2.82 \mathrm{ppt})$ was recorded in April while the lowest value $(0.08 \pm 0.11 \mathrm{ppt})$ was observed in June Total Dissolved solid (TDS) ranged between 264.47 and $958.33 \mathrm{mg} / \mathrm{l}$. the month of April had the highest value $(958.33 \pm 834.84 \mathrm{mg} / \mathrm{l})$ while the lowest value $(264.47 \pm 46.71 \mathrm{mg} / \mathrm{l})$ was observed in June (Table 1).

Spatial mean value of water physiochemical parameter indicates that dissolved oxygen ranged between 3.65 and $4.68 \mathrm{mg} / \mathrm{l}$. Station 3 recorded the highest value $(4.68 \pm 0.58 \mathrm{mg} / \mathrm{l})$ while the lowest value $(3.65 \pm 1.08 \mathrm{mg} / \mathrm{l})$ was observed in Station 1 . Temperature ranged between $27.60^{\circ} \mathrm{C}$ and $28.84^{\circ} \mathrm{C}$, Station 1 had the highest mean value $\left(28.84^{\circ} \mathrm{C} \pm 1.44^{\circ} \mathrm{C}\right)$ while the lowest value $\left(27.60^{\circ} \mathrm{C} \pm\right.$ $0.27^{\circ} \mathrm{C}$ ) was observed in Station 3. $\mathrm{pH}$ ranged between 5.26 and 5.75, Station 1 had the highest mean value $(5.75 \pm 0.32)$ while the lowest value $(5.26 \pm 0.28)$ was recorded in Station 3. Electrical conductivity ranged between 512.67 and 1588.67 $\mu \mathrm{s} / \mathrm{cm}$, Station 1 had the highest mean value $(1588.67 \pm 1165.36 \mu \mathrm{s} / \mathrm{cm})$ while the lowest value $(512.67 \pm 870.35 \mu \mathrm{s} / \mathrm{cm})$ was observed in Station 3. Biological oxygen

Table 1. Monthly mean values of water physiochemical parameters.

\begin{tabular}{|c|c|c|c|c|c|}
\hline Variables & April & May & June & Overall mean & Range \\
\hline D.O (mg/l) & $4.00 \pm 1.44^{\mathrm{b}}$ & $4.37 \pm 0.35^{\mathrm{a}}$ & $4.16 \pm .0 .68^{\mathrm{a}}$ & $4.17 \pm 0.83$ & $4.00-4.37$ \\
\hline Temperature $\left({ }^{\circ} \mathrm{C}\right)$ & $29.27 \pm 1.57^{\mathrm{a}}$ & $27.83 \pm 0.38^{\mathrm{a}}$ & $27.92 \pm 0.1^{\mathrm{a}}$ & $28.34 \pm 1.07$ & $27.83-29.27$ \\
\hline $\mathrm{pH}$ & $5.22 \pm 0.21^{\mathrm{a}}$ & $5.81 \pm 0.22^{\mathrm{a}}$ & $5.53 \pm 3.41^{\mathrm{a}}$ & $5.52 \pm 0.34$ & $5.22-5.81$ \\
\hline E.C $(\mu \mathrm{s} / \mathrm{cm})$ & $1762.67 \pm 1028.60^{\mathrm{a}}$ & $1203.33 \pm 601.31^{\mathrm{b}}$ & $405.67 \pm 68.53^{c}$ & $1123.89 \pm 839.58$ & $405.67-1762.67$ \\
\hline Salinity (ppt) & $2.44 \pm 2.82^{\mathrm{a}}$ & $1.89 \pm 2.44^{\mathrm{b}}$ & $0.08 \pm 0.11^{\mathrm{c}}$ & $1.47 \pm 2.15$ & $0.08-2.44$ \\
\hline TDS (mg/l) & $958.33 \pm 834.84^{\mathrm{a}}$ & $571.40 \pm 246.60^{\mathrm{b}}$ & $264.47 \pm 46.71^{\mathrm{c}}$ & $589.13 \pm 529.58$ & $264.47-958.33$ \\
\hline
\end{tabular}

Mean with similar superscript along the horizontal row are not significantly different at $P \leq 0.05$. 
demand (BOD) ranged between 4.18 and $4.97 \mathrm{mg} / \mathrm{l}$, the highest mean value $(4.97 \pm$ $1.38 \mathrm{mg} / \mathrm{l})$ was observed in Station 3 while the lowest value $(4.18 \pm 1.04 \mathrm{mg} / \mathrm{l})$ was recorded in Station 2. Salinity ranged between 0.19 and $3.51 \mathrm{ppt}$ with Station 1 having the highest value $(3.51 \pm 2.91 \mathrm{ppt})$ while the lowest value $(0.19 \pm 0.30$ ppt) was observed in Station 3. Total dissolved solid ranged between 329 and $908.07 \mathrm{mg} / \mathrm{l}$ with Station 1 having the highest mean value $(908.07 \pm 885.67 \mathrm{mg} / \mathrm{l})$ while the lowest value $(329 \pm 106.78 \mathrm{mg} / \mathrm{l})$ was recorded in Station 3 (Table 2).

Monthly mean value of heavy metal concentration in water indicate that $\mathrm{Zn}$ ranged between 1.43 and $2.17 \mathrm{ppm}$ with on overall mean of $1.77 \pm 0.53 \mathrm{ppm}$, April had the highest mean value $(2.17 \pm 0.65 \mathrm{ppm})$ while the lowest value $(1.43 \pm$ $0.55 \mathrm{ppm}$ ) was recorded in June. Chromium ranged between 0.56 and $0.78 \mathrm{ppm}$ with and overall mean of $0.65 \pm 0.21 \mathrm{ppm}$. The highest mean value $(0.78 \pm 0.27$ ppm) was recorded in April while the lowest mean value (0.56 $\pm 0.12 \mathrm{ppm})$ was observed in June. Lead ranged between 0.12 and $0.29 \mathrm{ppm}$ with an overall mean value of $0.19 \pm 0.11 \mathrm{ppm}$, April had the highest mean value $(0.29 \pm 0.16 \mathrm{ppm})$ while the lowest value $(0.12 \pm 0.02 \mathrm{ppm})$ was recorded in June. Iron ranged between 1.18 - $1.82 \mathrm{ppm}$, April had the highest mean value (1.82 $\pm 0.28 \mathrm{ppm})$ while the lowest mean value (1.18 $\pm 0.22 \mathrm{ppm}$ ) was observed in June (Table 3$)$. Spatial heavy metal concentration mean value in water observed is such that: $\mathrm{Zn}$ ranged between 1.35 and $6.33 \mathrm{ppm}$ in which the highest mean value $(6.33 \pm 0.75 \mathrm{ppm})$ was recorded in Station 1 while Station 3 had the lowest value $(1.35 \pm 0.27 \mathrm{ppm})$. Cr ranged between 0.47 and $0.89 \mathrm{ppm}$ in which Station 2 had the highest mean value $(0.86 \pm 0.19 \mathrm{ppm})$ while the lowest value was observed in Station $3 . \mathrm{Pb}$ ranged between 0.15 and $0.27 \mathrm{ppm}$ such that Station 1 had the highest mean value $(0.27 \pm 0.19 \mathrm{ppm})$ while the lowest value $(0.15 \pm 0.05 \mathrm{ppm})$ was observed in Station 3. Iron concentration in water ranged between 1.20 and $1.68 \mathrm{ppm}$, Station 1 and the highest value $(1.68 \pm 0.31 \mathrm{ppm})$ while the lowest value $(1.20 \pm 0.25$ ppm) was observed in Station 3 (Table 4).

The result of monthly mean value of heavy metal concentration in sediment observed, is such that $\mathrm{Zn}$ ranged between 6.42 and $12.36 \mathrm{ppm}$ with the overall mean $7.90 \pm 12.59$. ppm. April had the highest mean value $(12.36 \pm 12.36 \mathrm{ppm})$ while the lowest value $(6.42 \pm 6.42 \mathrm{ppm})$ was recorded in the month June; $\mathrm{Cr}$

Table 2. Spatial mean value of water physiochemical parameters.

\begin{tabular}{cccccc}
\hline Variables & ST 1 & ST 2 & ST 3 & Overall mean & Range \\
\hline D.O $(\mathrm{mg} / \mathrm{l})$ & $3.65 \pm 1.08^{\mathrm{b}}$ & $4.19 \pm 2.13^{\mathrm{B}}$ & $4.68 \pm 0.58^{\mathrm{a}}$ & $4.17 \pm 0.83$ & $3.65-4.68$ \\
Temperature $\left({ }^{\circ} \mathrm{C}\right)$ & $28.34 \pm 1.44^{\mathrm{a}}$ & $28.57 \pm 5.03^{\mathrm{a}}$ & $27.60 \pm 0.27^{\mathrm{a}}$ & $28.34 \pm 1.07$ & $27.60-28.84$ \\
$\mathrm{pH}$ & $5.75 \pm 0.32^{\mathrm{a}}$ & $5.55 \pm 0.32^{\mathrm{a}}$ & $5.26 \pm 0.28^{\mathrm{a}}$ & $5.52 \pm 0.34$ & $5.26-5.75$ \\
E.C $(\mu \mathrm{s} / \mathrm{cm})$ & $1588.67 \pm 1165.32^{\mathrm{a}}$ & $1270.33 \pm 716.98^{\mathrm{b}}$ & $512.67 \pm 870.35^{\mathrm{c}}$ & $1123.89 \pm 839.58$ & $512.67-1588.67$ \\
BOD $(\mathrm{mg} / \mathrm{l})$ & $4.19 \pm 1.04^{\mathrm{a}}$ & $4.18 \pm 1.04^{\mathrm{a}}$ & $4.97 \pm 1.38^{\mathrm{b}}$ & $4.45 \pm 1.14$ & $4.18-4.97$ \\
Salinity $(\mathrm{ppt})$ & $3.51 \pm 2.91^{\mathrm{a}}$ & $0.70 \pm 0.66^{\mathrm{b}}$ & $0.19 \pm 0.30^{\mathrm{b}}$ & $1.47 \pm 2.15$ & $0.19-3.51$ \\
TDS $(\mathrm{mg} / \mathrm{l})$ & $908.07 \pm 885.67^{\mathrm{a}}$ & $885.67 \pm 927.94^{\mathrm{a}}$ & $329 \pm 106.78^{\mathrm{b}}$ & $598.13 \pm 529.58$ & $329-908.07$ \\
\hline
\end{tabular}

Mean with similar superscript along the horizontal row are not significantly different at $P \leq 0.05$. Key: ST $1=$ Station 1 , ST $2=$ Station 2 , ST $3=$ Station 3 . 
Table 3. Monthly mean values of heavy metals in water.

\begin{tabular}{cccccc}
\hline Variables & April & May & June & Overall mean & Range \\
\hline $\mathrm{Zn}(\mathrm{ppm})$ & $2.17 \pm 0.65^{\mathrm{a}}$ & $1.72 \pm 0.36^{\mathrm{b}}$ & $1.43 \pm 0.0 .55^{\mathrm{b}}$ & $1.77 \pm 0.53$ & $1.43-2.17$ \\
$\mathrm{Cr}(\mathrm{ppm})$ & $0.78 \pm 0.27^{\mathrm{a}}$ & $0.61 \pm 0.24^{\mathrm{a}}$ & $0.56 \pm 0.12^{\mathrm{a}}$ & $0.65 \pm 0.21$ & $0.56-0.78$ \\
$\mathrm{~Pb}(\mathrm{ppm})$ & $0.29 \pm 0.16^{\mathrm{a}}$ & $1.17 \pm 0.07^{\mathrm{b}}$ & $0.12 \pm 0.02^{\mathrm{b}}$ & $0.19 \pm 0.11$ & $0.12-0.29$ \\
$\mathrm{Fe}(\mathrm{ppm})$ & $1.82 \pm 0.28$ & $1.40 \pm 0.27^{\mathrm{b}}$ & $1.18 \pm 0.22^{\mathrm{b}}$ & $1.52 \pm 0.34$ & $1.18-1.82$ \\
\hline
\end{tabular}

Mean with similar superscript along the horizontal row are not significantly different at $P \leq 0.05$.

Table 4. Spatial mean values of heavy metals in water.

\begin{tabular}{cccccc}
\hline Variables & ST 1 & ST 2 & ST 3 & Overall mean & Range \\
\hline $\mathrm{Zn}(\mathrm{ppm})$ & $6.33 \pm 0.75^{\mathrm{a}}$ & $1.85 \pm 0.16^{\mathrm{b}}$ & $1.35 \pm 0.0 .27^{\mathrm{b}}$ & $1.77 \pm 0.53$ & $1.35-6.33$ \\
$\mathrm{Cr}(\mathrm{ppm})$ & $0.62 \pm 0.15^{\mathrm{a}}$ & $0.86 \pm 0.19^{\mathrm{a}}$ & $0.47 \pm 0.06^{\mathrm{b}}$ & $0.65 \pm 0.21$ & $0.47-0.86$ \\
$\mathrm{~Pb}(\mathrm{ppm})$ & $0.27 \pm 0.19^{\mathrm{a}}$ & $0.15 \pm 0.06^{\mathrm{b}}$ & $0.15 \pm 0.05^{\mathrm{b}}$ & $0.19 \pm 0.11$ & $0.15-0.27$ \\
$\mathrm{Fe}(\mathrm{ppm})$ & $1.68 \pm 0.31^{\mathrm{a}}$ & $1.53 \pm 0.41^{\mathrm{a}}$ & $1.20 \pm 0.25^{\mathrm{a}}$ & $1.52 \pm 0.34$ & $1.20-1.68$ \\
\hline
\end{tabular}

Mean with similar superscript along the horizontal row are not significantly different at $P \leq 0.05$. Key: ST $1=$ Station 1 , ST $2=$ Station 2 , ST $3=$ Station 3 .

ranged between 1.33 and $3.96 \mathrm{ppm}$ with an overall of mean of $1.94 \pm 0.81 \mathrm{ppm}$. April also had the highest mean value $(2.01 \pm 2.01 \mathrm{ppm})$, while the lowest value $(1.57 \pm 1.57 \mathrm{ppm})$ and observed in June. $\mathrm{Pb}$ ranged between 2.34 and $2.91 \mathrm{ppm})$ with an overall mean; 2:23 $\pm 0.61 \mathrm{ppm}$. April recorded the highest mean value $(2.91 \pm 2.91 \mathrm{ppm})$ while the lowest value $(2.34 \pm 2.34 \mathrm{ppm})$ was observed in May. Fe ranged between 89.42 and 96.49 ppm with an overall mean; $90.07 \pm 90.07$ ppm, April recorded the highest value; $(96.49 \pm 96.49 \mathrm{ppm})$, while the lowest value (89.42 $\pm 89.42 \mathrm{ppm}$ ) was observed in May (Table 5).

Result of the spatial mean value of heavy metal in sediment of the research indicate that $\mathrm{Zn}$ ranged between 5.51 and $9.29 \mathrm{ppm}$, Station 1 had the highest mean value $(9.29 \pm 2.97 \mathrm{ppm})$ while the lowest value $(5.51 \pm 0.69 \mathrm{ppm})$ was in Station 3. For Cr, it range observed between 1.40 and $2.64 \mathrm{ppm}$ with an overall mean of $1.94 \pm 0.81 \mathrm{ppm}$. Station 2 had the highest mean value $(2.64 \pm 1.15$ $\mathrm{ppm})$ which the lowest value $(1.40 \pm 0.37 \mathrm{ppm})$ was observed in Station 3. while $\mathrm{Pb}$ ranged between 1.48 and $2.62 \mathrm{ppm}$ with an overall mean of $2.23 \pm 0.61 \mathrm{ppm}$. Station 1 had the highest mean value, $2.62 \pm 0.29 \mathrm{ppm}$ while the lowest mean value (1.48 $\pm 0.09 \mathrm{ppm})$ was observed in Station 3. Fe ranged between 79.44 and $91.99 \mathrm{ppm}$ with an overall mean; $87.43 \pm 6.57 \mathrm{ppm}$. Station 1 had the highest mean value while the lowest mean value $(79.44 \pm 2.02 \mathrm{ppm})$ was observed in Station 3 (Table 6).

Correlation was also obtained during the research work were Chromium $(\mathrm{Cr})$ correlated strongly positive $(0.688)$ with Zinc $(\mathrm{Zn})$ with $\mathrm{P}>0.05$, lead correlated strongly (0.673) and positively with Zinc $(\mathrm{Zn})$ at $\mathrm{P}>0.05$, while lead also correlated strongly positive $(0.877)$ with chromium at $\mathrm{P}<0.05$. Iron $(\mathrm{Fe})$ correlated positively strongly with Zinc (0.631), chromium (0.752) and $\mathrm{Pb}(0.825)$ were $\mathrm{P}<$ 0.05 for chromium and lead while $\mathrm{P}>0.05$ for Zinc. This is as shown in (Table 7). Correlation of heavy metals in water and physiochemical parameters was 
Table 5. Monthly mean values of heavy metals in sediment.

\begin{tabular}{cccccc}
\hline Variable & April & May & June & Overall Mean & Range \\
\hline $\mathrm{Zn}(\mathrm{ppm})$ & $12.36 \pm 12.36^{\mathrm{a}}$ & $9.10 \pm 9.10^{\mathrm{b}}$ & $6.42 \pm 6.42^{\mathrm{c}}$ & $7.90 \pm 2.59$ & $6.42-12.36$ \\
$\mathrm{Cr}(\mathrm{ppm})$ & $2.01 \pm 2.01^{\mathrm{a}}$ & $1.72 \pm 1.72^{\mathrm{b}}$ & $1.57 \pm 1.57^{\mathrm{c}}$ & $1.94 \pm 0.81$ & $1.57-2.01$ \\
$\mathrm{~Pb}(\mathrm{ppm})$ & $2.91 \pm 2.91^{\mathrm{a}}$ & $2.34 \pm 2.34^{\mathrm{b}}$ & $2.61 \pm 2.61^{\mathrm{c}}$ & $2.23 \pm 0.61$ & $2.34-2.91$ \\
$\mathrm{Fe}(\mathrm{ppm})$ & $96.49 \pm 96.49^{\mathrm{a}}$ & $89.42 \pm 89.42^{\mathrm{b}}$ & $90.07 \pm 90.07^{\mathrm{c}}$ & $87.43 \pm 6.57$ & $89.42-96.49$ \\
\hline
\end{tabular}

Mean with similar superscript along the horizontal row are not significantly different at $P \leq 0.05$.

Table 6. Spatial mean values of heavy metals in sediment.

\begin{tabular}{cccccc}
\hline Variable & ST 1 & ST 2 & ST 3 & Overall Mean & Range \\
\hline $\mathrm{Zn}(\mathrm{ppm})$ & $9.29 \pm 2.97^{\mathrm{a}}$ & $8.92 \pm 2.10^{\mathrm{b}}$ & $5.51 \pm 0.69^{\mathrm{c}}$ & $7.90 \pm 2.59$ & $5.51-9.29$ \\
$\mathrm{Cr}(\mathrm{ppm})$ & $1.77 \pm 0.22^{\mathrm{a}}$ & $2.64 \pm 1.15^{\mathrm{b}}$ & $1.40 \pm 0.27^{\mathrm{c}}$ & $1.94 \pm 0.81$ & $1.40-2.61$ \\
$\mathrm{~Pb}(\mathrm{ppm})$ & $2.62 \pm 0.29^{\mathrm{a}}$ & $2.59 \pm 0.36^{\mathrm{a}}$ & $1.48 \pm 0.09^{\mathrm{a}}$ & $2.23 \pm 0.61$ & $1.48-2.62$ \\
$\mathrm{Fe}(\mathrm{ppm})$ & $91.99 \pm 3.91^{\mathrm{a}}$ & $90.85 \pm 3.01^{\mathrm{b}}$ & $79.44 \pm 2.02^{\mathrm{c}}$ & $87.43 \pm 6.57$ & $79.44-91.99$ \\
\hline
\end{tabular}

Mean with similar superscript along the horizontal row are not significantly different at $P \leq 0.05$. Key: ST $1=$ Station 1 , ST $2=$ Station 2 , ST $3=$ Station 3 .

Table 7. Correlations of heavy metal in sediment.

\begin{tabular}{|c|c|c|c|c|}
\hline & $\mathrm{Zn}$ & $\mathrm{Cr}$ & $\mathrm{Pb}$ & $\mathrm{Fe}$ \\
\hline $\mathrm{Zn}$ & 1.00 & & & \\
\hline Sig. (2 tailed) & - & & & \\
\hline $\mathrm{Cr}$ & 0.688 & 1.00 & & \\
\hline Sig. (2 tailed) & 0.059 & - & & \\
\hline $\mathrm{Pb}$ & 0.673 & 0.877 & 1.00 & \\
\hline Sig. (2 tailed) & 0.068 & 0.004 & - & \\
\hline $\mathrm{Fe}$ & 0.631 & 0.752 & 0.825 & 1.00 \\
\hline Sig. (2 tailed) & 0.093 & 0.032 & 0.012 & - \\
\hline
\end{tabular}

observed were DO had a negative correlation with other parameters and heavy metals.

Temperature observed a negative correlation with $\mathrm{pH}$ and $\mathrm{DO}$ while with other variables, recorded positive correlation. $\mathrm{pH}$ had a negative correlation with $\mathrm{DO}$, temperature, $\mathrm{Cr}, \mathrm{Pb} \& \mathrm{Fe}$ while with other variables recorded positive correlation. Electrical conductivity had a negative correlation with DO and a positive correlation with other variables. BOD had a negative correlation with DO, $\mathrm{Cr}$ and $\mathrm{Fe}$ while a positive correlation was recorded with other variables. Salinity had a negative correlation with DO and a positive correlation with other variables. TDS observed a negative correlation with $\mathrm{DO}$ and positive correlation with other variable. $\mathrm{Zn}$ had a Negative correlation with $\mathrm{DO}$ and a positive correlation with other variable. $\mathrm{Cr}$ observed a negative correlation with $\mathrm{DO}, \mathrm{pH}$ and BOD while with other variables observed a positive correlation. $\mathrm{Pb}$ recorded a Negative correlation with $\mathrm{DO} \& \mathrm{pH}$ while position correlation was observed with other variables. Fe had a Negative correlation with DO, $\mathrm{pH}$ and BOD while with other variable observed-positive correlation. Significant difference was also 
observed for the variables were $\mathrm{P}<0.05$ indicate significant and values of $\mathrm{P}>$ 0.05 indicate no significant difference (Table 8 ).

\section{Discussion}

The effect of water physiochemical parameters on heavy metal concentration are consistent with that of Kaizer and Osakwe [57]; that temperature affect the concentration of heavy metal in the aquatic environment. That as temperature increase, the level of heavy metal also increase in the aquatic environment. It is also in agreement that the level of dissolved oxygen in an aquatic environment is inversely affected by the concentration of heavy metals.

The high value in electrical conductivity may be attributed to the increase level of heavy metal concentration in the water. Also it might be that as temperature increases, evaporation takes place and the concentration of ions present in the water will also increase which are also component of trace metals in the aquatic environment. The effect of total dissolve solid to heavy metals are in consistent with Dara [58] which implies that TDS are solid particles which dissolved in water. This solid comes into the aquatic environment as a result of runoff

Table 8. Pearson correlation significant (2 Tailed) of physiochemical parameters and heavy metals in water.

\begin{tabular}{|c|c|c|c|c|c|c|c|c|c|c|c|}
\hline & $\begin{array}{l}\text { D.O } \\
(\mathrm{mg} / \mathrm{l})\end{array}$ & $\begin{array}{c}\text { Temperature } \\
\left({ }^{\circ} \mathrm{C}\right)\end{array}$ & $\mathrm{pH}$ & $\begin{array}{c}\text { E.C } \\
(\mu \mathrm{s} / \mathrm{cm})\end{array}$ & $\begin{array}{l}\text { BOD } \\
(\mathrm{mg} / \mathrm{l})\end{array}$ & $\begin{array}{l}\text { Salinity } \\
\text { (ppt) }\end{array}$ & $\begin{array}{l}\text { TDS } \\
(\mathrm{mg} / \mathrm{l})\end{array}$ & $\begin{array}{c}\mathrm{Zn} \\
(\mathrm{ppm})\end{array}$ & $\begin{array}{c}\mathrm{Cr} \\
(\mathrm{ppm})\end{array}$ & $\begin{array}{c}\mathrm{Pb} \\
(\mathrm{ppm})\end{array}$ & $\begin{array}{c}\mathrm{Fe} \\
(\mathrm{ppm})\end{array}$ \\
\hline \multirow{2}{*}{ D.O (mg/l) } & 1 & & & & & & & & & & \\
\hline & - & & & & & & & & & & \\
\hline \multirow{2}{*}{ Temperature $\left({ }^{\circ} \mathrm{C}\right)$} & -0.637 & 1 & & & & & & & & & \\
\hline & 0.065 & - & & & & & & & & & \\
\hline \multirow{2}{*}{$\mathrm{pH}$} & -0.169 & -0.173 & 1 & & & & & & & & \\
\hline & 0.664 & 0.656 & - & & & & & & & & \\
\hline \multirow{2}{*}{ E.C $(\mu \mathrm{s} / \mathrm{cm})$} & -0.520 & $0.863^{* *}$ & 0.083 & 1 & & & & & & & \\
\hline & 0.151 & 0.003 & 0.831 & - & & & & & & & \\
\hline \multirow{2}{*}{ BOD (mg/l) } & -0.257 & 0.081 & 0.001 & 0.186 & 1 & & & & & & \\
\hline & 0.504 & 0.835 & 0.998 & 0.631 & - & & & & & & \\
\hline \multirow{2}{*}{ Salinity (ppt) } & -0.574 & 0.664 & 0.269 & $0.846^{* *}$ & 0.147 & 1 & & & & & \\
\hline & 0.092 & 0.051 & 0.484 & 0.004 & 0.705 & - & & & & & \\
\hline \multirow{2}{*}{ TDS (mg/l) } & $-0.690^{*}$ & $0.774^{*}$ & 0.015 & $0.868^{\star *}$ & 0.404 & $0.771^{\star}$ & 1 & & & & \\
\hline & 0.040 & 0.014 & 0.969 & 0.002 & 0.281 & 0.016 & - & & & & \\
\hline \multirow{2}{*}{$\mathrm{Zn}(\mathrm{ppm})$} & $-0.726^{*}$ & $0.815^{* *}$ & 0.091 & $0.907^{* *}$ & 0.028 & $0.854^{* *}$ & $0.852^{\star *}$ & 1 & & & \\
\hline & 0.027 & 0.007 & 0.816 & 0.001 & 0.943 & 0.003 & 0.004 & - & & & \\
\hline \multirow{2}{*}{$\mathrm{Cr}(\mathrm{ppm})$} & -0.232 & $0.730^{*}$ & -0.070 & $0.687^{*}$ & -0.105 & 0.267 & 0.442 & 0.581 & 1 & & \\
\hline & 0.547 & 0.547 & 0.857 & 0.041 & 0.788 & 0.487 & 0.234 & 0.101 & - & & \\
\hline \multirow{2}{*}{$\mathrm{Pb}(\mathrm{ppm})$} & $-0.705^{\star *}$ & $0.744^{*}$ & -0.096 & $0.811^{* *}$ & 0.260 & $0.850^{* *}$ & $0.931^{* *}$ & $0.874^{* *}$ & 0.264 & 1 & \\
\hline & 0.034 & 0.022 & 0.806 & 0.008 & 0.500 & 0.004 & 0.000 & 0.002 & 0.492 & - & \\
\hline \multirow{2}{*}{$\mathrm{Fe}(\mathrm{ppm})$} & -0.355 & $0.829^{* *}$ & -0.033 & $0.898^{* *}$ & -0.187 & $0.709^{*}$ & $0.697^{*}$ & $0.884^{\star *}$ & $0.694^{*}$ & $0.703^{*}$ & 1 \\
\hline & 0.349 & 0.006 & 0.932 & 0.001 & 0.630 & 0.032 & 0.037 & 0.005 & 0.034 & 0.035 & - \\
\hline
\end{tabular}

${ }^{*}$ Correlation is significant at the 0.05 level (2-tailed). ${ }^{*}$ Correlation is significant at the 0.01 level (2-tailed). 
from land carrying particles and minerals which could result to heavy metals in the aquatic environment.

According to Eddy and Ukpong [59]. The relationship of $\mathrm{pH}$ and Minerals is dependent on the kind of mineral abundance in the aquatic environment. Heavy metal present in the water tend to affect the temperature of the water which in turn affect the $\mathrm{pH}$ attaining neutrality (pH7). Salinity is in consistent with Uyi [60]. That as salinity increases temperature also increase which also affect the concentration of metals in water. Metals are known to be ionizable ions which upon reaction can displace $\mathrm{H}^{+}$and form salt with $\mathrm{Cl}^{-}$which implies that the increase in salinity in water is as a result of the increased concentration of heavy metal ions present in water. This is also the reason why sample station with high salinity recorded high level of heavy metal concentration. The positive correlation between biological oxygen demand and heavy metal might be attributed to the fact that when heavy metal increase they assumed the "toxic level" which create toxic effect to Aqua-organisms resulting to death of many and as such increases the oxygen required for decomposition of the organisms which is BOD. According to Eddy et al., [61]. Zinc is a major heavy metal which comes into the aquatic environment from domestic waste. The mean concentration of zinc in the study area was lower when compared with the concentration of 50ppm reported by Roster and Lange [62] for river sediment samples. The positive correlation between zinc and other heavy metal suggest that the source of input of zinc into the river might be the same when compared to the source of input of other heavy metals. Gumgum et al; [63], had a contrary observed between Zinc and other heavy metals in the sediment.

The mean concentration of $\mathrm{Pb}$ in the sediment was below the concentration of 10ppm reported by Roster and Lange [62] for River sediment samples. This implies that the river is not highly polluted with respect to $\mathrm{Pb}$ and it source of input into the river system can be attributed to anthropogenic activities. The concentration of $\mathrm{Fe}$ in the sediment was observed to be higher when compared with values reported by Eddy et al. [61] and Dara [58] and was observed to be in consistent with Eddy and Ukpong [59]. The high of concentration level of iron in water and sediment is capable of causing corrosion of materials such as pipelines and can cause health problem [58]. The source of iron into the aquatic environment include scraps of iron metal thrown into the river, domestic waste and iron containing effluent from industries.

The concentration of heavy metals in the study area was higher in sediment as compare to water which is in consistent with the finding of Opaluwa et al., [13]. The high level of Iron in this river may be due to the dumping of water vessel which oxidized and are situated to the sediment. Which is in agreement with Opaluwa et al. [13]. The mean concentration of heavy metals in the sediment where industrial effluent and runoff from agricultural land enters the river stream changes similarly in two seasons. In other words the average concentration of heavy metal accumulation in the sediment is lower in raining seasons 
than in dry season. April had a high concentration of heavy metal concentration in the sediment than June which could be attributed to high rain fall which resulted in the rapid dilution of the aquatic environment and give rise to flow of the water in the river. Due to the turbulence created by increase of flow, some sediment are carried away and displaced from the river bottom. During the Dry season (April experience Minimal rainfall as compared to June) Evaporation and temperature tend to be higher than in raining season which is in line with Ahmed et al. [64].

There are also indication of increasing occurrence of heavy metal in the studied area which are principally attributed to anthropogenic activities such as the combustion of fuel by oil installations and automobiles, petrochemical industries, dredging industries and other domestic activities [57]. However, the level of heavy metal in both water and sediment varied significantly in sampling station: which is due to industrial activities carried out in the sampling station. Station 1 (Ogbogoro) has a high level of heavy metal in both water and sediment which is due to the increase industrial activities carried out in the studies Area.

\section{Conclusions}

The level of heavy metal is related with the physiochemical characteristic of the Upper New Calabar River in which some of the parameters have a positive correlation with the heavy metals while others have a negative correlation. Observations made during this research also indicated that water is the first point of contamination before the sediments. It has also shown that the level of heavy metal concentration in sediment is high as compared to that of water. Heavy metals are term as pollutant only when they assume their toxic level as some of them are needed by organisms for survival in minute quantity. Anthropogenic activities such as industrial activities, dumping of motorized aquatic vessels, domestic waste discharge are the major source of heavy metals in the aquatic environment while Natural activities such as runoff from: agricultural land, building site, Road construction area into the aquatic environment are also source in which heavy metals enters the aquatic environment.

It is therefore recommended that:

- Continuous monitoring of heavy metals concentration in water and sediment should be encouraged to attain the level of pollution in the aquatic environment. Sampling duration should be increase to ascertain the increasing level of pollution all year round.

- Adequate and proper enforcement activities should be carried out to ensure that companies sited around the New Calabar River observed proper waste management treatment measures before discharging to the water body. Dumping of scrap in the New Calabar River should not be encouraged.

\section{References}

[1] Fergusson, J.E. (1990) The Heavy Elements: Chemistry, Environmental Impact and Health. Pergamon Press, Oxford. 
[2] Amman, A.A., Michalke, B. and Schramet, P. (2002) Speciation of Heavy Metals in Environmental Water by Ion Chromatography Coupled to ECP-MS. Biochemistry, 372, 448-452.

[3] Di Maio, V.J.M. (2001) Forensic Pathology. 2nd Edition, CRC Press.

[4] Perry, J. and Vanderklein, E.L. (1996) Water Quality Management of Matira; Respsrices B. aclwescoemce.

[5] Tuzen, M. (2003) Determination of Heavy Metal in Fish Samples of Middle Black Sea (Turkey) by Graphite Furnace Atomic Absorption Spectronmetry. Food Chemistry, 80, 119-173. https://doi.org/10.1016/S0308-8146(02)00264-9

[6] Dural, M., Gosku, M.Z.L. and Ozak, A.A. (2007) Investigation of Heavy Metal Levels in Economically Important Fish Species Captured Form the Tuzla Lagoon. Food Chemistry, 102, 415-421. https://doi.org/10.1016/j.foodchem.2006.03.001

[7] Howard, I.C., Gabriel, U.U. and Nduka, J.O. (2009) Bioaccumulation of Heavy Metals in Periphthalnuspapillo and Tympanotonusfuscatus from the Mangrove Swamps in Oil Field in Niger Delta.

[8] Chinda, A.C. and Nduaguibe, U. (2003) Effects of Tarn Farm Wastes on Water Quality and Periphyton of Lower Bonny River, Niger Delta, Nigeria. Journal of Nigerian Environmental Society, 1, 206-222.

[9] Bettinentti, R., Giarei, C. and Provini, A. (2003) A Chemical Anaysis and Sediment Toxicity Bioassays to Assess the Contamination of Rivers Lambro (Northern Italy). Archives of Environmental Contamination and Toxicology, 45, 72-75. https://doi.org/10.1007/s00244-002-0126-6

[10] Yi, Y., Yang, Z. and Zhang, S. (2012) Ecological Risk Assessment of Heavy Metals in Sediment and Human Health Risk Assessment of Heavy Metal in Fishes in the Middle and Lower Reaches of the Yangtse River Basin. Environmental Pollution, 159, 2576-2585.

[11] Suresh, G., Sutharsan, P., Romasamy, V. and Venkatacholapathy, R. (2012) Assessment of Spatial Distribution and Potential Ecological Risk of the Heavy Metals in Relation to Granulometric Contents of Vicranam Lake Sediments. India. Ecotoxicology and Environmental Safety, 84, 117-125. https://doi.org/10.1016/j.ecoenv.2012.06.027

[12] Odiete, W.O. (1999) Impacts Associated with Water Pollution in Environmental Physiology of Animal and Pollution. Diversified Resources Ltd., Lagos, 187-219.

[13] Opuluwa, O.D., Aremu, M.O., Ogbo, L.O., Magaji, J.I., Odiba, I.E. and Ekpo, E.R. (2012) Assessment of Heavy Metals in Water, Fish and Sediments Form UK. Stream, Nassarawa State, Nigeria. Journal of Current World Environment, 7, 213-220. https://doi.org/10.12944/CWE.7.2.04

[14] Davies, O.A., Allison, M.E. and Uyi, H.S. (2006) Bio Accumulation of Heavy Metals in Water Sediments and Periwinkle (Tympanotonusfus catusvarvadula) from Electri Creek, Niger Detta. African Journal of Biotechnology, 5, 10.

[15] Issa, B.R., Arimoro, O., Ibrahim, M., Birma, G.J. and Fadairo, E.A. (2011) Assessment of Sediment Contamination by Heavy Metals in River Orogodo. Journal of Environmental Science, 6, 29-38.

[16] US Environmental Protection Agency (EPA) (2005) National Management Measures to Control Non-Point Source Pollution for Urban Areas. Chapter 7 and 8, Document No. EPA 84 1-B-05-004, Washington DC.

[17] Forstner, U. and Wiltman, G.T. (1983) Metal Pollution in Aquatic Environment. 2nd Edition, Springer-Verlay, Berlin, 486 p. 
[18] Degregori, I., Pinochet, H., Arancibia, M. and Vida, A. (1996) Grown Size Effects on Trace Metal's Distribution in Sediment from Two Coastal Area of Chile. Bulletin of Environmental Contamination and Toxicology, 57, 163-170. https://doi.org/10.1007/s001289900170

[19] Fu, J. and Hazard, J. (2014) Heavy Metals in Surface Sediment of Jialu River, China: Their Relations to Environmental Factors. Journal of Hazardous Materials, 270, 102-109. https://doi.org/10.1016/j.jhazmat.2014.01.044

[20] Omotoyin, B.O. and Ajani, E.K. (2007) Feeding Habits and Bioaccumulation of Heavy Metals in Fishes of Eleyelelake, Nigeria. Journal of Afro-Topical Zoology, 165-169.

[21] Ayeloja, A.A., George F.O.A., Shorinmade, A.Y., Jimoh, W.A., Afolabi, Q.O. and Olwepo, K.D. (2014) Heavy Metal Concentration in Selected Fish Species from Eleyele Reservoir Ibadan Oyo State, South Western Nigeria. African Journal of Environmental Science and Technology, 8, 422-427. https://doi.org/10.5897/AJEST2014.1700

[22] Abowei, J.F.N. and Sikoki, F.D. (2005) Water Pollution Management and Control, Double Trust. Publication Company, Port Harcourt, 236 p.

[23] Mohammad, M., Sary, A.A. and Khodadadi, M. (2011) Determination of Heavy Metals in Two Barbs, Barbusgrypus and Barbusxanthopterus in Karoon and Dez Rivers, Khoozestan, Iran. Bulletin of Environmental Contamination and Toxicology, 87, 158-162. https://doi.org/10.1007/s00128-011-0302-3

[24] Amiard, J.C., Amiard-Triquet, C., Barko, S., Pellerin, J. and Rainbow, P.S. (2016) Metallothioneons in Aquatic Invertebrates: Their Role in Metal Detorification and Their Use as Biomarkers. Tрхосp, 76, 160-202.

[25] Dirican, S., Clilak, S., Clifter, H., Biyikeglu, M., Karaemar, S. and Yokus, A. (2015) Preliminary Study on Heavy Metal Concentration of Anetiliankhramulya, Lapoetatinca (Heckel, 1843) from Camlogozic Dam Like, Sivas Turkey. Journal of Environmental Health science and Engineering, 11, 1-6.

[26] Akpor, O.B. and Muchie, M. (2010) Remediation of Heavy Metals in Drinking Water and Wastewater Treatment Systems Processes and Applications. International Journal of Physical Sciences, 5, 1807-1817.

[27] Ayodele, J.T., Momoh, R.U. and Aminu, M. (2014) Determination of Heavy Metals in Sharaba: Industrial Effluents. In: Book of Abstracts. 2nd National Environmental Seminar, FEPA, F.M.H. Natural Water Resource Institute, W.H.O Kaduna State, Waterboard, 14.

[28] Abdulaziz, B.A. and Mohammad, H. (1997) Role of Epidemiological Studies in Determining Environmental Impact on Health in Saudi Aravia. In: Book of Abstracts. Development and Environmental Impact Conference, Biyadh, Saudi Arabia, 196 p.

[29] Jjemba, P.K. (2004) Environment Microbiology. Principles and Applications. Science Publishers Inc., Enfield.

[30] Harabawy, A.S.A. and Mosleh, Y.Y.I. (2014) The Role of Vitamins A, C, E and Selenium as Antioxidants against Genotoxicity and Cytotoxicity of Cadmium, Copper, Lead and Zinc on Erythrocytes of Nile Tilapia, Oreochromis niloticus. Ecotoxicology and Environmental Safety, 104, 28-35. https://doi.org/10.1016/j.ecoenv.2014.02.015

[31] Silva, J., Heuser, V. and Amdrade, V. (2003) Bio Monitoramento Ambiental. In: Ebahj, S.J., Ed., Genetica Toxicological, Alcance, Porto Alegre, 167-178.

[32] FAO/WHO Food and Agricultural Organisation/World Health Organisation (1997) Expert Committee Tool Additives World Health Organization. Geneva-WHO 
Technical Report Series (FAO), Rome, 20-26.

[33] O’Connor, M.I. (2006) Temperature Control of Larval Dispersal and the Implications for Marine Ecology, Evolution and Conservation. Proceedings of the National Academy of Sciences, 104, 1266-1271. https://doi.org/10.1073/pnas.0603422104

[34] Goldman, C.R. and Horne, A.J. (1983) Limnology. McGraw-Hill Book Co., New York, $464 \mathrm{p}$.

[35] Ibim, A.T., Gogo, O.O. and Igbani, F. (2016) The Ichthyofaunal Assemblage of the Lower and Upper Reaches of New Calabar River, Rivers State, Niger Delta, Nigeria. Journal Environment and Earth Science, 6, 21-23.

[36] Lau, S., Mohammed, M.A., Tan, C.Y. and Sut-S, S. (1998) Accumulation of Heavy Metals in Freshwater Mollusks. The Science of the Total Environment, 214, 115-121. https://doi.org/10.1016/S0048-9697(98)00058-8

[37] WHO (1985) Guidelines for Drinking Water Quality. Vol. 2: Health Criteria and Supporting Information. Vol. 1: Recommendations. WHO, Geneva, 130.

[38] Fondriest Environment Inc. FEI (2014) Conductivity, Salinity and Total Dissolved Solid. Fundamentals of Environmental Measurements.

http://www.fondriest.com/environmental-measurements/parameters/water-quality/ conductivity-salinity-TDS/

[39] Abowei, J.F.N. and Ezekiel, E.N. (2003) Aspects of Some Physicochemical Parameters of the Fresh Water Reaches of the Lower Nun River, Niger Delta. International Journal of Science and Technology (IJST), 1, 40.

[40] Chindah, A.C. and Braide, S.A. (2003) Cadium and Lead Concentrations in Fish Species of a Brackish Wetland Upper Bonny Estuary, Niger Delta. Journal of Nigerian Water Environment, 1, 399-405.

[41] Daka, E.R., Ifidi, I. and Braide, S.A. (2006) Effect of Size and Salinity on the Accumulation of Heavy Metals in the Intertidal Gastropod Tympanotonus fuscatus Linnaeus. African Journal of Environmental Pollution and Health, 5, 1-7.

[42] Boyd, C.E. and Liichtkoppler, F. (1779) Water Quality Management in Fish Pond. Research and Development, Series No. 22, International Centre for Aquaculture and Agriculture, Experimental Station, Auburn University, Alabama, 45-47.

[43] Erondu, S.E. and Chinda, A.C. (1991) Variation in the Physico-Chemical Features and Phytoplankton of the New Calabar River at Aluu Rivers State, Nigeria. NIOMR Tech. Paper No. 75.

[44] Madu, P.C., Tagwoi, J.T. and Babalola, F.A. (2008) A Study of Heavy Metal Pollution of River Antau, Keffi, Nasarawa State, Nigeria. Indian Journal of Multi. Research, 4, 8-18.

[45] Kaley, M., Aly, O. and Canil, M. (1999) Heavy Metal Concentration in Fish Disuse Form the North East Mediteranean Sea, Bulletin of Enron. Contamination and Toxicity, 63, 673-671. https://doi.org/10.1007/s001289901033

[46] King, R.P. and Nkanta, N.A. (1992) The Status and Seasonality in the Physico-Chemical Hydrology of a Nigerian Rainforest Pond. Journal of Limnology, 52, $1-2$.

[47] Macfarlane, G.B. and Burchett, M.D. (2000) Cellular Distribution of Cu, Pb and $\mathrm{Zn}$ in the Grey Mangrove Avicemnia marina (Forsk) Vierh. Aquatic Botany, 68, 45-59. https://doi.org/10.1016/S0304-3770(00)00105-4

[48] Aremu, M.O., Atolaiye, B.O., Shagye, D. and Moumouni, A. (2007) Determination of Trace Metals in TIilapia zillo and clariaslazera Fishes Associated with Water and Soil Sediment from Nasarawa, in Nasaraw State, Nigeria. India. J. Multi. Res., 3, 
159-168.

[49] Galloway, J.N., Thornton, J.D., Norton, S.A., Volchok, H.L. and Mcilean, H.L. (1982) Trace Metals in Atmospheric Depositions, a Review and Assessment. At mospheric Environment, 16, 1677-1700. https://doi.org/10.1016/0004-6981(82)90262-1

[50] Ekweozor, I.K.E. (2014) Appraisal of Industrialization and Environmental Pollution: A Marine Biology Perspective. 29th Inaugural Lecture of the Rivers State University of Science and Technology, Port Harcourt, 185.

[51] Carins, J.A., Heath, G. and Parker, B.C. (1975) Temperature Influence on Chemical Toxicity to Aquatic Organisms. Water Pollution Control Federation, 47, 267-280.

[52] Ababio, O.Y. (2006) New School Chemistry for African Schools. Africana First Limited, $423 \mathrm{p}$.

[53] Khan, S., Cao, Q., Zheng, Y.M., Huang, Y.Z. and Zhu, Y.G. (2008) Health Risks of Metals in Contaminated Soils and Food Crops Irrigated with Waste Water in Beying. China Journal of Environmental Pollution, 152, 686-692. https://doi.org/10.1016/j.envpol.2007.06.056

[54] Guy, D. (1992) The Ecology of the Fish Pond Ecosystem with Special Reference to Africa. Pergamon Press, Oxford, 220-230.

[55] Ukwa, U.D., Akinsaya, B. and Saliu, J.K. (2015) Parasite Load, Condition Factor and Heavy Metal Accumulation a Multiple Stressors on Fish in Lekk, Lagoon Lagos, Nigeria. 1st Annual SETAC Central and West Africa Conference, Enugu, 28-30 January 2015, No. 1410.

[56] Langston, W.J. and Spence, S.K. (1994) Metal Analysis. In: Calow, P., Ed., Handbook of Ecotoxicology, Blackwell Scientific, Oxford, 45-78.

[57] Kaizer, A.N. and Osakwe, S.A. (2010) Physiochemical Characteristics and Heavy Metal Levels in Water Sample from Five River Systems in Delta State, Nigeria. Journal of Applied Sciences and Environmental Management, 14, 83-87. https://doi.org/10.4314/jasem.v14i1.56501

[58] Dara, S.S. (1993) A Textbook of Environmental Chemistry and Pollution Control. S. Chand and Company Ltd., New Delhi.

[59] Eddy, N.O. and Ukpong, I.J. (2005) Heavy Metal Concentration in Upper Calabar River Sediments South Eastern Nigeria. African Journal Environmental Pollution, 4, 38-43.

[60] Uyi, H.S. (2005) Bioaccumulation of Heavy Metals (Cr, Cd and Pb) in Periwinkle; Tympanotanus furcatus var, radula from Elechi Creek Niger Delta. Bachelor of Science Project, in Fisheries and Aquatic Environment, Rivers State University of Science and, Nkpolu-Oroworukwo, Port Harcourt, 41.

[61] Eddy, O.O., Udo, C.L. and Ukpong, I.J. (2004) Heavy Metals in Sediment from the Cross River of Oron-Afr. Journal of Environmental Pollution and Health, 1, 6-10.

[62] Roster, H.H. and Lange, H. (1972) Geochemical Tables. Elsevier Pub. Comp., Amsterdam, London, New York.

[63] Gumgum, B., Unlu, E., Tez, Z. and Gulsun, Z. (1994) Heavy Metal Pollution in Water, Sediment and Fish from the Tigris River in Turkey. Chemosphere, 29, 111-116. https://doi.org/10.1016/0045-6535(94)90094-9

[64] Ahmed, M.K., Baki, M.A., Islam, M.S., Kundu, G.K., Sakar, S.K. and Hossain, M.M. (2015) Human Health Risk Assessment of Heavy Metals in Tropical Fish and Shell Fish Collected from the River Buriganga, Bangladesh. Environmental Science and Pollution Research International, 22, 15880-15890.

https://doi.org/10.1007/s11356-015-4813-z 